Atmos. Chem. Phys., 10, 2457-2465, 2010

www.atmos-chem-phys.net/10/2457/2010/

(C) Author(s) 2010. This work is distributed under

the Creative Commons Attribution 3.0 License.

\title{
Continental scale Antarctic deposition of sulphur and black carbon from anthropogenic and volcanic sources
}

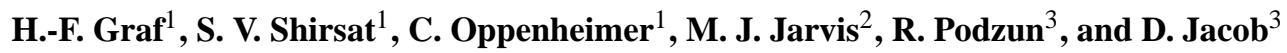 \\ ${ }^{1}$ University of Cambridge, Geography Department, Cambridge, UK \\ ${ }^{2}$ British Antarctic Survey, Cambridge, UK \\ ${ }^{3}$ Max-Planck-Institute for Meteorology, Hamburg, Germany
}

Received: 8 October 2009 - Published in Atmos. Chem. Phys. Discuss.: 11 December 2009

Revised: 1 March 2010 - Accepted: 5 March 2010 - Published: 11 March 2010

\begin{abstract}
While Antarctica is often described as a pristine environment, there is an increasing awareness of the potential threats from local pollution sources including tourist ships and emissions associated with scientific activities. However, to date there has been no systematic attempt to model the impacts of such pollutants at the continental scale. Indeed, until very recently there was not even a sulphur emission budget available for Antarctica. Here we present the first comprehensive study of atmospheric pollution in Antarctica using a limited area chemistry climate model, and a monthly emissions inventory for sulphur from maintenance of research stations, ground and air traffic, shipping and the active Erebus volcano. We find that ship emissions, both sulphurous and black carbon, dominate anthropogenic pollution near the ground. Their prevalence is likely to rise dramatically if recent trends in tourism continue.
\end{abstract}

\section{Introduction}

The remote and mostly uninhabited continent of Antarctica was discovered in the late 18th century but forsaken except for sporadic expeditions until the International Geophysical Year in 1957/1958 when a number of permanent research stations were established. Today, 37 year-round and 16 summer-only research bases operate in Antarctica, of which McMurdo (managed by the US Antarctic Program) is the

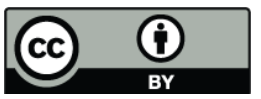

Correspondence to: H.-F. Graf (hfg21@cam.ac.uk) largest with a population of around 1000 people during the austral summer (November to March) and of 250 during winter (April to October). The history of tourism in Antarctica also dates back to the 1950s. In 2000 an international organization was created (IAATO, www.iaato.org) to monitor and regulate tourist activity in the region. Their reports reveal a strongly increasing number of tourist visits from 12248 to about 46000 between the 2001/2002 and the 2007/2008 seasons, with an anticipation of further growth. Most of the tourists (98\%) are ship borne.

Several prior studies have investigated pollution due to research activity at stations. $\mathrm{PM}_{10}$ abundance measured in McMurdo during the austral summer routinely exceeds levels found in remote coastal regions of the continent ( $\mathrm{Lu}-$ gar, 1993; Mazzera et al., 2001). Another study (Wolff and Cachier, 1998) conducted during 1992-1995 measured Black Carbon (BC) at Halley research station and found a mean background atmospheric level of approximately $1 \mathrm{ng} \mathrm{BC} \mathrm{m}^{-3}$, and spikes of several hundred $\mathrm{n} \mathrm{BC} \mathrm{m}^{-3} 350$ $400 \mathrm{~m}$ downwind of the generators. It was also suggested that the annual cycle of $\mathrm{BC}$ from its timing appears to be controlled by biomass burning in the tropics, strongly modulated by the efficiency of transport to Antarctica. In a more recent study Stohl and Sodemann (2010) assessed long-range transport of $\mathrm{BC}$ towards Antarctica excluding any loss processes along the transport path. They conclude that it is "unlikely for air from these continents to reach Antarctica on time scales relevant for aerosols and many short-lived trace gases". This makes local sources of pollution especially relevant.

Published by Copernicus Publications on behalf of the European Geosciences Union. 
Table 1. Emissions from sulphur inventory (6) in $\mathrm{Mg} \mathrm{SO}_{2}$ month ${ }^{-1}$.

\begin{tabular}{lrrrc}
\hline Source & Station & Ship & Aircraft & Erebus \\
\hline April & 4 & - & & 2229 \\
May & 4 & - & & 2229 \\
June & 4 & - & & 2229 \\
July & 4 & - & & 2229 \\
August & 4 & - & & 2229 \\
September & 4 & - & & 2229 \\
October & 4 & - & & 2229 \\
November & 26 & 223 & 6.4 & 2229 \\
December & 26 & 1971 & 5.6 & 2229 \\
January & 26 & 769 & 21.3 & 2229 \\
February & 26 & 693 & 21.2 & 2229 \\
March & 26 & 217 & 1.3 & 2229 \\
\hline
\end{tabular}

Other pollutant sources include combustion of fuel for transport and energy production, sewage burning (banned after 1997) and accidental oil spills (Bargagli, 2008), for example from shipping accidents such as befell the Antarctic cruise vessel "Explorer" in 2007 or the "Bahia Paraiso" accident in 1989 where $6 \times 10^{5} 1$ of oil were spilled. Most of these studies concerned point measurements in the proximity of research stations (for a comprehensive review on the effects of human presence in Antarctica see Tin et al., 2009), and we are unaware of any study of continental scale contamination. Only very recently was a first comprehensive emission inventory published for 2004/2005 (Shirsat and Graf, 2009).

Natural sources of pollution include Erebus volcano, whose summit crater reaches $3794 \mathrm{~m}$ above sea level on Ross Island, and which has probably been degassing continuously from its active lava lake since at least its discovery in 1972 (Giggenbach et al., 1973). Between 1992 and 2005, the average of all $\mathrm{SO}_{2}$ flux measurements for the volcano was $61 \mathrm{Mg} \mathrm{d}^{-1}\left(\sim 1860 \mathrm{Mg} \mathrm{month}^{-1}\right.$; Sweeney et al., 2008) very similar to measurements made in 2006 (Boichu et al., 2010). In December 2003, ultraviolet spectroscopy indicated that Erebus volcano is also an important source of $\mathrm{NO}_{\mathrm{x}}$ (Oppenheimer et al., 2005). This finding was substantiated by in situ sampling of the drifting plume with an instrumented aircraft, which revealed significant abundances of volcanogenic $\mathrm{HNO}_{3}$ and $\mathrm{HO}_{2} \mathrm{NO}_{2}$ as well as ozone depletion likely due to a combination of reactive halogen and $\mathrm{NO}_{\mathrm{x}}$ chemistry (Oppenheimer et al., 2010). Several sporadically active volcanoes are located in the outer South Sandwich and Shetland Islands, but their emissions have not been measured and they are not taken into account here.

Oceanic and coastal biota (mainly penguins) also contribute to atmospheric pollution as does the emission of $\mathrm{NO}_{\mathrm{x}}$ from snow pack (Wang et al., 2008). Marine bioactivity leads to the emission of dimethylsulphate (DMS), which oxidises to $\mathrm{SO}_{2}$ and, ultimately, to sulphate in the atmosphere. Estimates of source strength range between 1.4 and $2.7 \mathrm{Tg} \mathrm{Syr}^{-1}$ for the Southern Ocean (Berresheim, 1987; Curran and Jones, 2000) but their transformation into other sulphur species and subsequent deposition is highly uncertain (Boucher et al., 2003). In any case, these sources by far exceed anthropogenic emissions of sulphur species and mask the contribution from anthropogenic sources. In order to determine the patterns of anthropogenic sulphur deposition we therefore exclude DMS sources from our study. The modelled distributions of sulphur emissions may also be seen as giving a guide to the potential dispersal of other, potentially more toxic chemical species that are emitted concurrently but not treated in our model.

The weather and climate of Antarctica are dominated by strong katabatic winds blowing from the continent's interior towards the open ocean and by strong westerlies with embedded synoptic storms encircling the continent between $60^{\circ} \mathrm{S}$ and $40^{\circ} \mathrm{S}$, making the region extremely windy, cloudy and precipitation rich. Most human activity is concentrated in coastal areas with relatively easy access in summer, when the prevailing weather conditions tend to hinder transport of airborne pollutants towards the interior of the continent.

\section{Emission inventory}

We use a new emissions inventory (Shirsat and Graf, 2009) in a model simulation of transport, chemical transformation and deposition of sulphur compounds and BC (from ship emissions only) for the year 2004/2005. The emissions from each source (station activity, ground transport, aviation, ships, and emissions from Erebus volcano) were tagged to allow comparison of their individual contributions to the total atmospheric abundance and deposition. Station activity including ground transport contributes $158 \mathrm{Mg}$ of $\mathrm{SO}_{2}$ for April 2004 to March 2005 , only $18 \mathrm{Mg}$ more than an earlier estimate (Boutron and Wolff, 1989). Aircraft operations contribute $56 \mathrm{Mg}$ of $\mathrm{SO}_{2}$ at varying altitudes but exclusively during the Antarctic summer.

By far the highest anthropogenic source during the 2004/2005 summer season is shipping: $3.873 \mathrm{Gg}$ of $\mathrm{SO}_{2}$ and $14.5 \mathrm{Mg}$ of $\mathrm{BC}$. This is 40 times more $\mathrm{SO}_{2}$ than the estimated total shipping source south of $60^{\circ} \mathrm{S}$ in 1989 (Boutron and Wolff, 1989)! Bond et al. (2007) as quoted by Stohl and Sodemann (2010) estimated the total BC emission from ships south of $60^{\circ} \mathrm{S}$, including fishery activities, as $100 \mathrm{Mg}$ per year, an amount exceeding our BC emission data by a factor of $\sim 7$. The number of ship visits to Antarctica, including scientific missions, support of station operations and tourism, is rising. In the Antarctic summer (November to March) 2004/2005, 65\% of all ships carried tourists (Shirsat and Graf, 2009) and their number rose from 210 trips in $2004 / 2005$ (our study period) to 301 trips in the 2007/2008 austral summer, an increase of $43 \%$ within three years. 
Human activity on the continent is highly localised around bases, with the highest populations found on the Antarctic Peninsula, in the Ross Sea area (Ross Island and Terra Nova Bay), Queen Maud Land and around the Amery Ice Shelf. Even though the sulphur emission of Erebus volcano is more than six times higher than all anthropogenic emissions, the crater is $\sim 3800 \mathrm{~m}$ above sea level allowing winds to dilute and disperse the plume over a much greater area than the near-ground emissions.

Estimates of total emissions of $\mathrm{SO}_{2}$ from different source types are shown in Table 1. They are based on emission factors for different fuel types and fuel consumption. The latter quantity is either based on reported values or was estimated from gross data on a per capita basis. For a detailed description of the methods see Shirsat and Graf (2009). During the austral winter, station activity is reduced and ship operations and aviation cease. Station emissions were distributed to the base locations and, where known, to transport routes according to available information. In many cases, only the seasonal total of burned fuel was available. If one nation operates several stations, national total fuel use was then distributed on a per capita basis to the station locations. Ship routes and mooring times were obtained from a number of different sources, including the on-line ship tracking system (www.sailwx.info) and sea ice maps. Air operations peak in January and February when research activity is highest. They had to be estimated taking into account different modes of operation during take-off, climb, approach and cruise using data on travel route, number of flights (intercontinental and intra-continental) and fuel consumption by aircraft operations in Antarctica as obtained from COMNAP and personal communications.

As seen from Table 1, ship emissions dominate anthropogenic sources during the Antarctic summer. The busiest month is December when, in $2004, \mathrm{SO}_{2}$ emission was comparable to volcanic emissions. Considering the dramatic $>40 \%$ increase in tourist activity between 2004 and 2007 it is possible that December ship emissions today exceed those from Erebus volcano. BC emissions were estimated only for ships. They are based on an emission factor of $0.18 \times 10^{-3}$. It remains unclear if the lower emission of $\mathrm{BC}$ in our inventory compared to the numbers reported in Bond et al. (2007) is due to our rather conservative emission factor or comes from exclusion of fishery activities. Very possibly our estimates represent a lower limit.

\section{Model simulations}

To estimate the contribution of each source to the total deposition and atmospheric abundance of anthropogenic sulphur, we ran the 20 layer limited area model REMOTE (Langmann, 2000) at $0.5^{\circ}$ resolution from April 2004 to March 2005. The model resolution smoothes the topography (especially steep slopes). The model meteorology was driven at the lateral boundaries every $6 \mathrm{~h}$ by ECMWF ERA 40 reanalysis data (Uppala et al., 2005) after initialization at all grid points on 1 April 2004. Gas phase RADM2 (Stockwell et al., 1990) sulphur chemistry was included and both wet (Walcek and Taylor, 1986) and dry (Wesley, 1989) deposition were calculated. We concentrate on anthropogenic effects from point and line sources (mainly stations and ships) and Erebus volcano and did not take into account the uncertain background emissions and transformation pathways of DMS in our model study. The model was applied over Antarctica for the first time and so we checked winds and temperatures against observations and reanalysis data. Surface temperatures from the model simulation were compared with available observations at Halley, Syowa, Dumont d'Urville, Neumayer and McMurdo. Both temperatures agree within a range of $2-3^{\circ} \mathrm{C}$. A comparison of three day mean temperatures from ECMWF reanalysis with our model data yields correlations between 0.8 and 0.9 , while wind speeds are less well correlated $(r=0.9$ at the lateral boundaries of the model domain dropping to $r=0.5$ to 0.6 in the interior of the continent). Overall, the results showed good agreement and made us confident that the model is a useful tool for our task.

The mean lifetime of $\mathrm{SO}_{2}$ was estimated from the model calculations as 2 weeks in summer and 3 weeks in winter, comparable to estimates for the Arctic (Barrie and Hoff, 1984). Figure 1 shows atmospheric mixing ratios of $\mathrm{SO}_{2}$ in the lowest model level (ca. $50 \mathrm{~m}$ height above surface) for December 2004, the month with highest anthropogenic emissions, originating from i) station activity and ground traffic, (ii) ships and (iii) Erebus volcano. Clearly the highest abundance of $\mathrm{SO}_{2}$ from research activity is found where most of the stations are situated, i.e., around the largest station (McMurdo) in the Ross Sea, and on Amery Ice Shelf and in Queen Maud Land, where clusters of bases operate. Weather conditions over the Peninsula, where further research bases are found, reduce the build up of $\mathrm{SO}_{2}$ abundance since oxidation is faster here due to higher temperatures, atmospheric moisture and insolation. The rate of oxidation of $\mathrm{SO}_{2}$ into sulphate leads to a much smoother distribution of sulphate in the lowest model level, but still the dominating ship source can be traced. Once sulphate is formed it is quickly washed out from the atmosphere. The maximum anthropogenic sulphate (gas phase plus condensed) concentration reaches $0.01 \mathrm{ppbv}$ close to McMurdo and just north of the tip of the Peninsula (Fig. 1d), where they contribute less than $20 \%$ to volcanic plus anthropogenic atmospheric concentration. Most tourist ships are bound for the Peninsula region since its attractions are easier to access. $\mathrm{SO}_{2}$ abundances from ship operation are thus especially high in this area, contributing at least ten times as much as research bases.

Emissions from Erebus volcano reveal high surface $\mathrm{SO}_{2}$ abundance extending from the crater Island to adjacent areas of the Ross Sea and Transantarctic Mountains. Because of the high summit elevation, they are distributed more evenly 

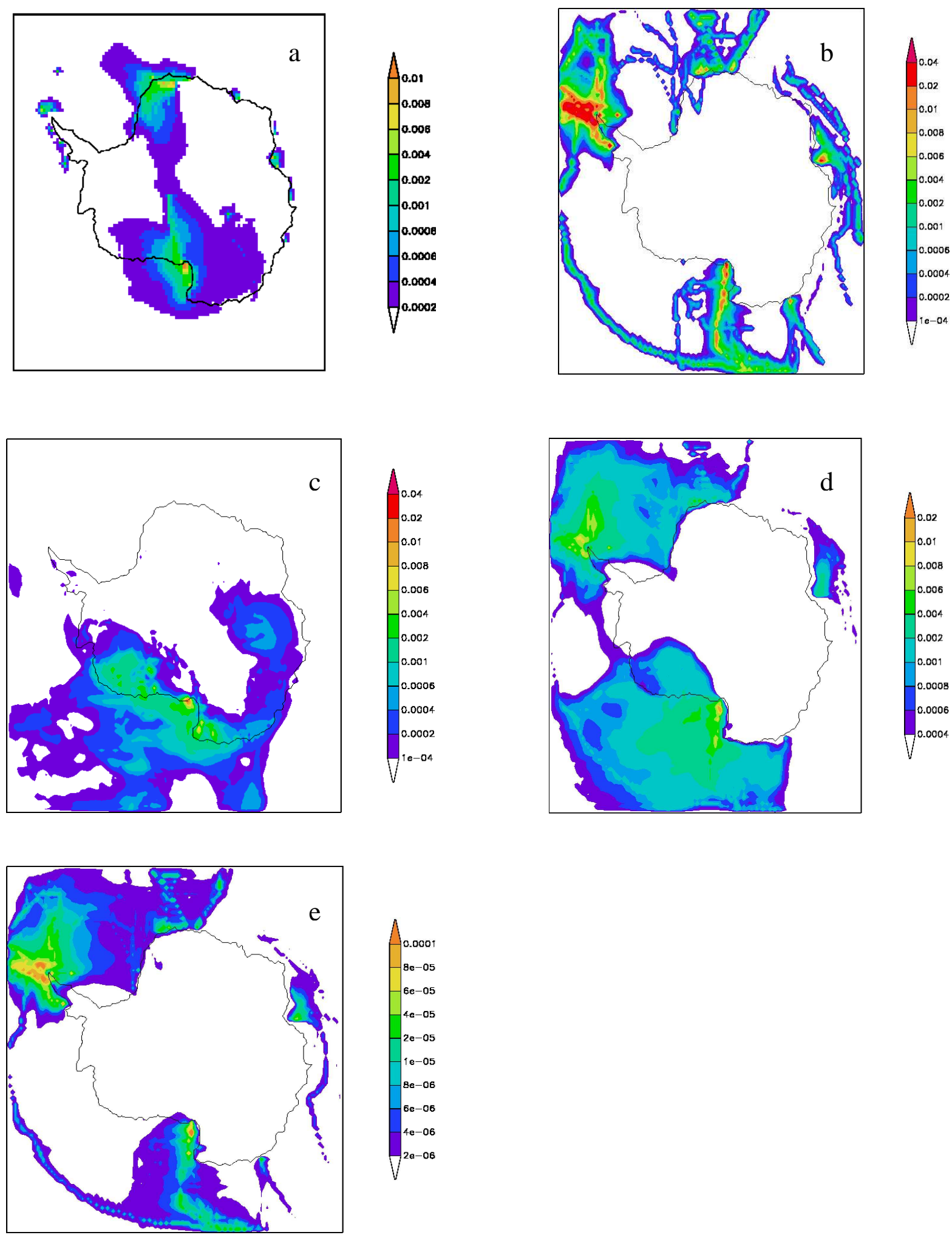

Fig. 1. Monthly mean December 2004 mixing ratio in ppbv at lowest model level (a) $\mathrm{SO}_{2}$ from power generation and vehicle operation at and between stations, (b) $\mathrm{SO}_{2}$ from ship emissions and (c) $\mathrm{SO}_{2}$ from volcanic emissions, sulphate concentration from all these sources (d) and black carbon from ships (e). 

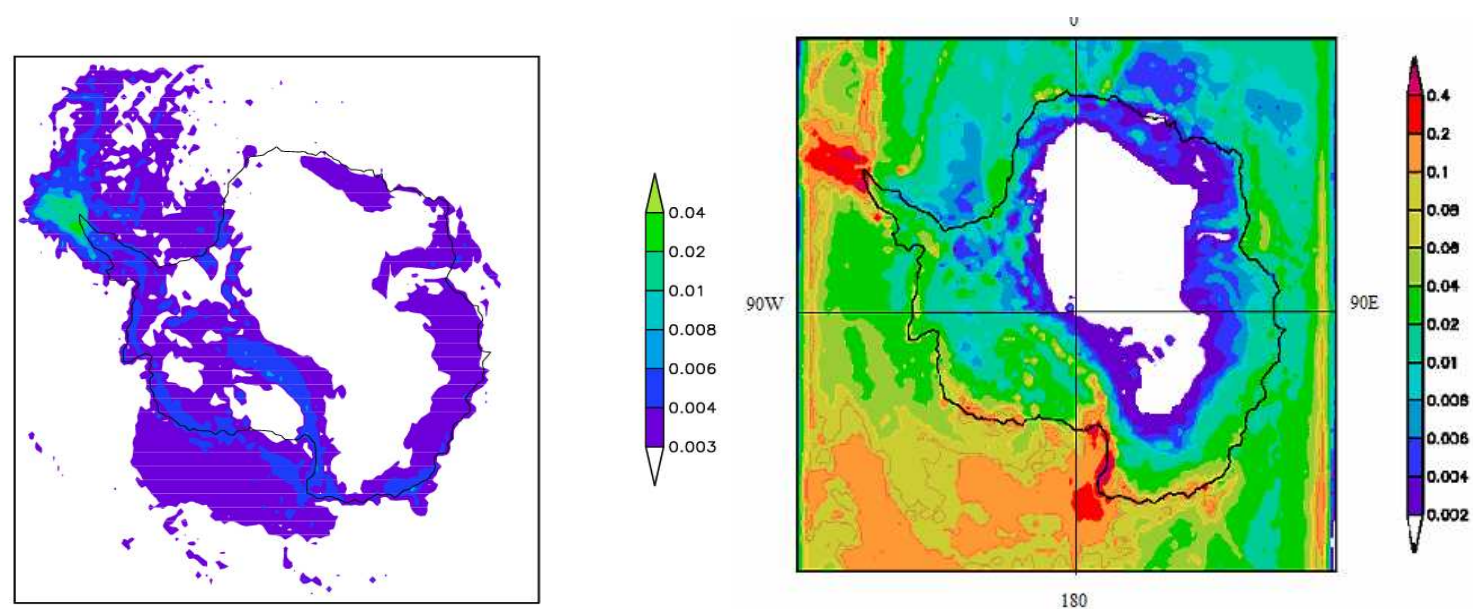

Fig. 2. Annual deposition in $\mathrm{kg} \mathrm{km}^{-2}$ of Black Carbon (BC) from ships (left) and of Sulphur from stations, volcano and ships (right).

and over a wider area than the near surface emissions from ships and station activity.

Clearly, even the highest simulated grid cell means of atmospheric $\mathrm{SO}_{2}$ abundances from anthropogenic sources are well below observed local values elsewhere in the world, including the Arctic. In Nuuk, Greenland, between February 2002 and August 2004, mean $\mathrm{SO}_{2}$ concentrations of $0.44 \mu \mathrm{g} \mathrm{m}^{-3}$ were reported (Skov et al., 2006), an order of magnitude higher than the maximum values we simulated for Antarctica from emissions of research bases and ship operation (Peninsula $0.035 \mathrm{~g} \mathrm{~g} \mathrm{~m}^{-3}$ and Ross Island $0.057 \mu \mathrm{g} \mathrm{m}^{-3}$ ). Erebus volcano contributes significantly to the $\mathrm{SO}_{2}$ abundance in the Ross Sea area, with a mixing ratio of $\sim 0.020 \mu \mathrm{g} \mathrm{m}^{-3}(\sim 6.4 \mathrm{pptv})$. Aviation related atmospheric sulphur abundance remains several orders of magnitude below all other sources. We have to keep in mind, however that sulphur from the oceanic DMS source is excluded in the simulations and that the model results represent means for areas of about $2500 \mathrm{~km}^{2}$ and cannot, therefore, capture local maxima, especially in the vicinity of strong point sources. Observations (Wolff and Cachier, 1998) revealed an average $\mathrm{SO}_{2}$ concentration of $0.74 \mu \mathrm{g} \mathrm{m}^{3}$ ( $\left.\sim 250 \mathrm{pptv}\right)$ near McMurdo Station during the austral summers 1995/1996 and 1996/1997 and Eisele et al. (2008) reported $\mathrm{SO}_{2}$ measurements at South Pole of about 10 pptv. This point measurement exceeds the Nuuk observations, and represents a much higher abundance than our model simulations yield for the area mean. Abundances representative of the scale of our model are not available, but since all relevant emission sources are point or line (cruising ships) sources, variations of one to two orders of magnitude can be expected within the model resolved grid cells.

The only BC source considered in this study is shipping. As seen in Fig. 1e, maximum mixing ratios are $<0.1$ pptv even in the most contaminated areas around the Peninsula. Such low concentrations do not significantly affect radiation processes and, hence, we will concentrate on cumulative effects of deposition.

Melted snow is the exclusive source of fresh water in Antarctica and therefore deposition of sulphur and BC is important. Sulphur and BC deposition may also serve as an indicator for the deposition of other, more toxic co-emitted substances including trace metals, especially from ship diesel engines. During melting or by evaporation from the snow pack, any pollutants become more concentrated enhancing the potential to affect ecosystems.

The total modelled deposition of sulphur (from $\mathrm{SO}_{2}$ and $\mathrm{SO}_{4}$ ) and of BC from ship exhaust during the year 2004/2005 is plotted in Fig. 2. Black carbon deposition reaches its highest rates at the outer Peninsula, where most shipping activity takes place. The maximum local concentrations of $\mathrm{BC}$ in snow just reach the order of $1 \mathrm{ng} \mathrm{g}^{-1} \mathrm{BC}$. The reduction in albedo of snow is $\sim 1.5 \%$ for $10 \mathrm{ng} \mathrm{g}^{-1}$ of $\mathrm{BC}$ in snow (Hansen and Nazarenko, 2004), so the present pollution can only affect snow albedo marginally. However, with further increases in shipping in the Peninsula region, significant effects on snow albedo may arise. Most of the deposition of sulphur takes place into the Southern Ocean since the prevailing winds blow the pollutants away from the continent. However, maximum deposition rates exceeding $0.4 \mathrm{~kg} \mathrm{~S} \mathrm{~km}^{-2}$ are found along the coast of Ross Sea $\left(0.54 \mathrm{~kg} \mathrm{~S} \mathrm{~km}^{-2}\right)$ and stretching from the tip of the Antarctic Peninsula towards the Southern Ocean $\left(0.85 \mathrm{~kg} \mathrm{~S} \mathrm{~km}^{-2}\right)$. The western hemisphere, where sources are concentrated, experiences generally higher deposition rates and the interior of the continent remains nearly unaffected due to the strong katabatic winds directed towards the ocean.

There are large differences between winter and summer deposition patterns resulting from the seasonal contribution from anthropogenic sources, but also due to seasonal differences in weather conditions and sulphur photochemistry (Fig. 3). Sulphur deposition is due mainly to dry deposition 

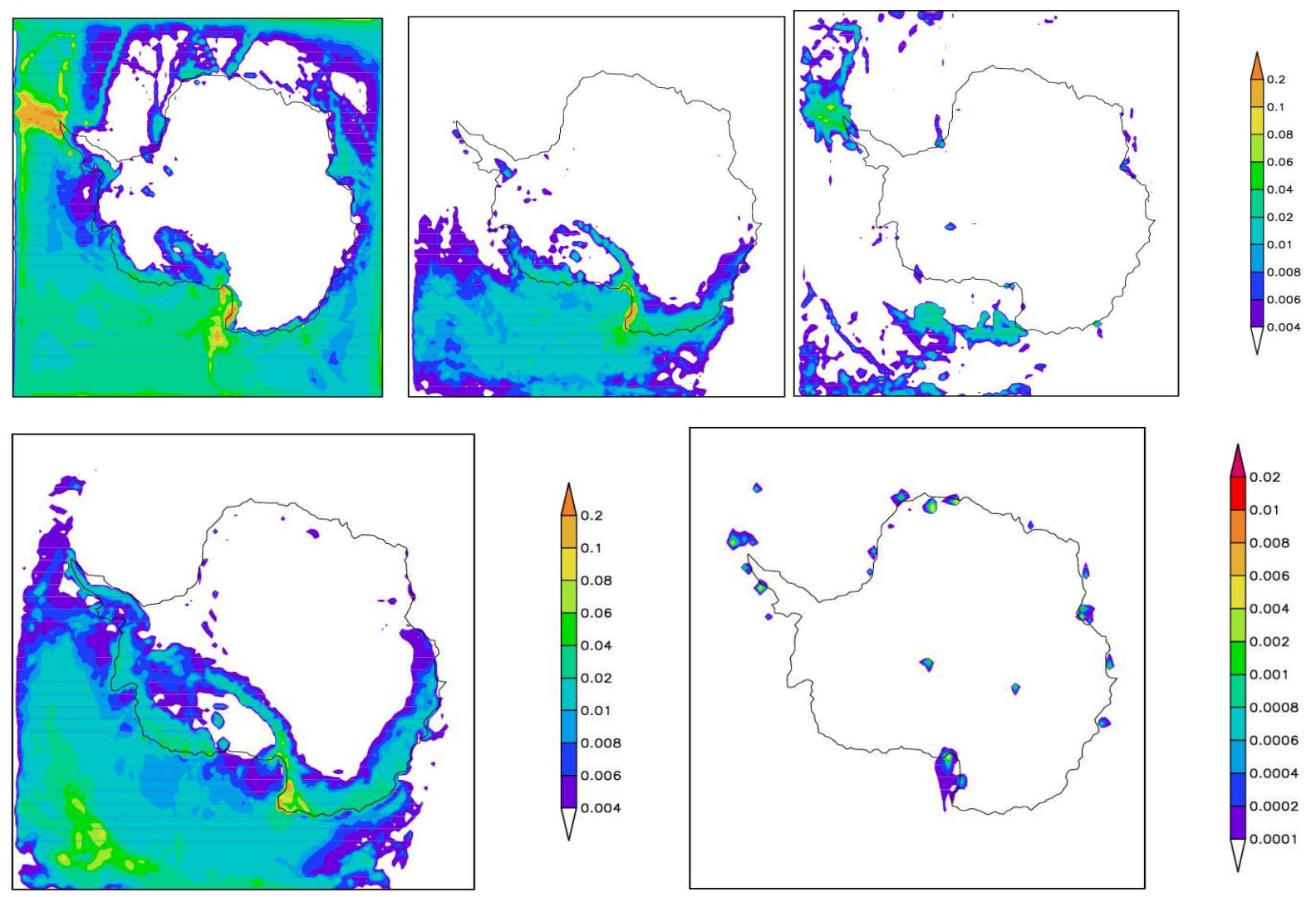

Fig. 3. Top: Sulphur deposition (wet + dry) in $\mathrm{kg} \mathrm{km}^{-2}$ from Ships (left), Erebus volcano (middle) and station activity (right) in $\mathrm{kg} \mathrm{S} \mathrm{km}^{-2}$ during Antarctic summer. Bottom: Sulphur deposition (wet + dry) in $\mathrm{kg} \mathrm{km}^{-2}$ from Erebus volcano (left) and station activity (right) in $\mathrm{kg} \mathrm{S} \mathrm{km}{ }^{-2}$ during Antarctic winter.

of $\mathrm{SO}_{2}$ and wet deposition of sulphate. From near surface sources (ships and stations) $\mathrm{SO}_{2}$ is deposited closer to the source and the amounts follow the cycle of activity with very low values in winter and higher ones in summer. Erebus volcano's emissions are distributed over a much wider area, but over the Royal Society mountain range considerable amounts of volcanic sulphur are deposited on snow by dry and wet processes. Since oxidation of $\mathrm{SO}_{2}$ to sulphate is reduced at low temperatures and in the absence of sunlight, in winter, sulphate from Erebus is barely formed before it reaches latitudes north of $60^{\circ} \mathrm{S}$, where it is then rapidly rained out over the open ocean. During summer, ship emissions clearly dominate the deposition of sulphur both in the Ross Sea area and to the north of the Peninsula as well as over large parts of the western Southern Ocean, wet deposition being the main process. We find two maxima, one over the Ross Sea and adjacent parts of the Southern Ocean, which originates from ship emissions and from Erebus volcano, and another stretching from the northern tip of the Peninsula into the Southern Ocean, where $98 \%$ results from ships and station activity. Aircraft do not contribute in any measurable way to surface deposition of sulphur species.
Figure 4 summarizes contributions from all sources to the total sulphur deposition at the outer Peninsula $\left(65^{\circ} \mathrm{S}\right.$, $\left.65^{\circ} \mathrm{W}\right)$, Ross Island $\left(77^{\circ} \mathrm{S}, 168^{\circ} \mathrm{E}\right)$, Queen Maud Land $\left(70^{\circ} \mathrm{S}, 11^{\circ} \mathrm{E}\right)$, Amery Ice Shelf $\left(69^{\circ} \mathrm{S}, 71^{\circ} \mathrm{E}\right)$, and South Pole for winter and summer. While in winter, Erebus volcano dominates S deposition at the Peninsula, Ross Island and Amery Ice Shelf, it has practically no effect at South Pole and Queen Maud Land, where local station emissions determine the very small deposition rates of sulphur. Again the prevailing circulation is responsible for these features. In summer, except for South Pole, ship emissions make by far the biggest contribution to sulphur deposition, with station emissions also a relevant source. Erebus, the biggest single sulphur source is of relative importance only at South Pole, where deposition rates are very small, and on Ross Island. Overall, pollution levels in Antarctica do not yet exceed any critical thresholds, as is already the case in the Arctic, but the rapid growth of human activity, especially mass tourism, may change this in the foreseeable future. 

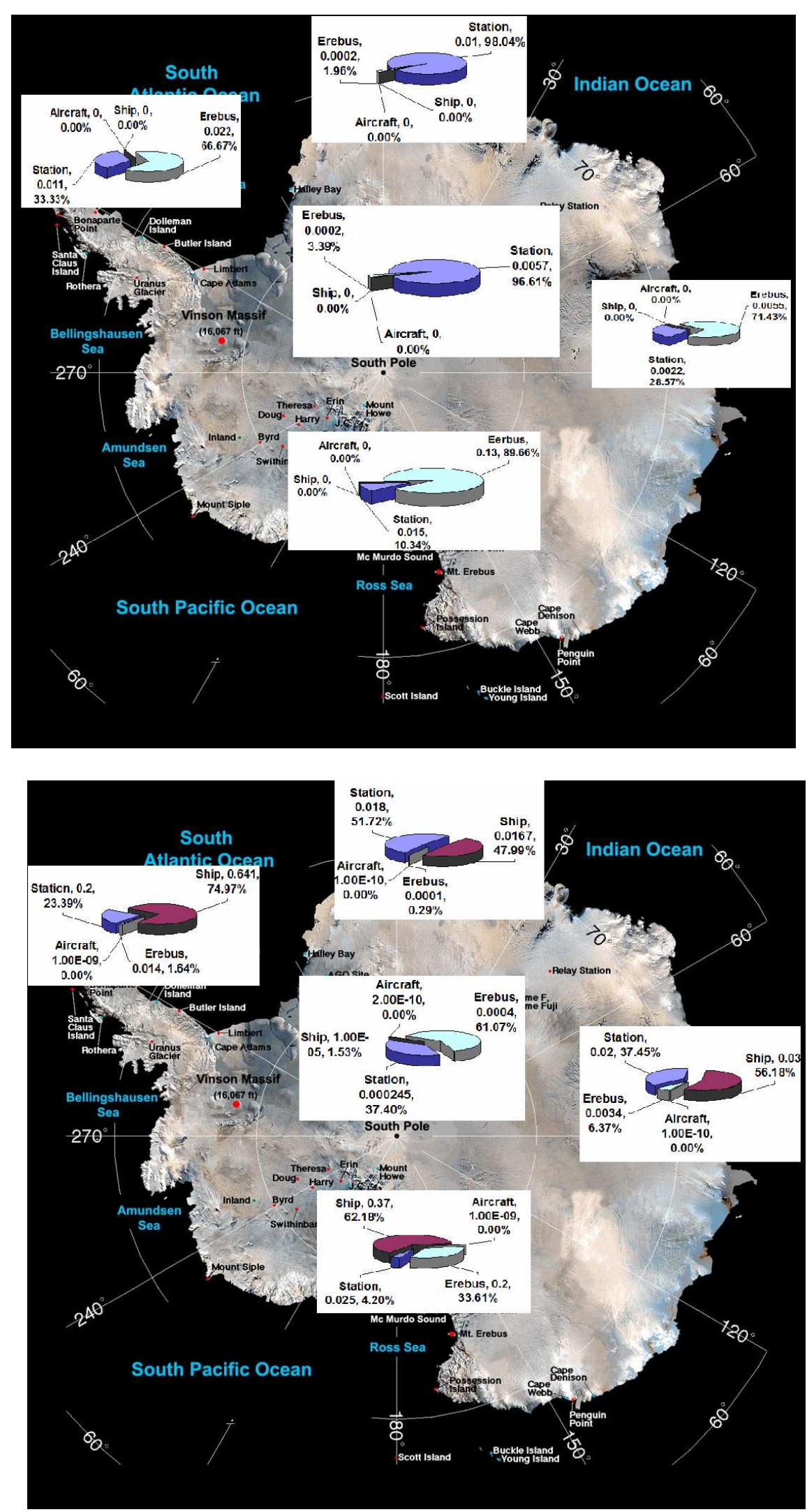

Fig. 4. Relative contribution of each emission source towards total (excluding DMS contribution) S deposition during winter (top) and summer (bottom) season of 2004/2005. 


\section{Conclusions}

Model simulations for the year 2004/2005 indicate ships as the most significant source of anthropogenic sulphur contamination during the austral summer, exceeding the natural source, Erebus volcano. Sulphur originating from oceanic DMS production is not included in this study. It generally will dominate the overall atmospheric concentration, thus obscuring anthropogenic contribution. Currently a new study is being prepared considering this source and reports will be reported later. Ships are the only source of BC considered here. Most of these ships are tourism related and the most affected areas are the outer Antarctic Peninsula, a main destination of tourist cruises, and the Ross Sea, where the biggest research station operates. While current atmospheric abundances and deposition of anthropogenic sulphur and black carbon do not seem to be critical, they may serve as indicators of contamination with other, more toxic substances, including heavy metals, polycyclic aromatic hydrocarbons and other toxic substances which are emitted especially together with BC, i.e. from ships. The simulated deposition patterns will help determine locations where snow samples can be collected to analyze large scale pollution in more detail.

Acknowledgements. We wish to thank Zoe Fleming and an anonymous reviewer for their constructive remarks during the discussion process.

Edited by: M. Dameris

\section{References}

Bargagli, R.: Environmental contamination in Antarctic ecosystems, Sci. Total Environ., 400(1-3), 212-226, doi:10.1016/j.scitotenv.2008.06.062, 2008.

Barrie, L. A. and Hoff, R. M.: The oxidation rate and residence time of sulphur dioxide in the Arctic atmosphere, Atmos. Environ., 18(12), 2711-2722, 1984.

Berresheim, H.: Biogenic sulfur emissions from the Subantarctic and Antarctic oceans, J. Geophys. Res., 92, 1324513262, 1987.

Boichu, M., Oppenheimer, C., Tsanev, V. I., and Kyle, P. R.: High temporal resolution $\mathrm{SO}_{2}$ flux measurements at Erebus volcano, Antarctica, J. Volcanol. Geoth. Res., 190, 325-336, 2010.

Bond, T. C., Bhardwaj, E., Dong, R., Jogani, R., Jung, S., Roden, C., Streets, D. G., Fernandes, S., and Trautmann, N.: Historical emissions of black and organic carbon aerosol from energyrelated combustion, 1850-2000, Global Biogeochem. Cy., 21, GB2018, doi:10.1029/2006GB002840, 2007.

Boucher, O., Moulin, C., Belviso, S., Aumont, O., Bopp, L., Cosme, E., von Kuhlmann, R., Lawrence, M. G., Pham, M., Reddy, M. S., Sciare, J., and Venkataraman, C.: DMS atmospheric concentrations and sulphate aerosol indirect radiative forcing: a sensitivity study to the DMS source representation and oxidation, Atmos. Chem. Phys., 3, 49-65, 2003, http://www.atmos-chem-phys.net/3/49/2003/.
Boutron, C. F. and Wolff, E. W.: Heavy metal and sulphur emissions to the atmosphere from human activities in Antarctica, Atmos. Environ., 23(8), 1669-1675, 1989.

COMNAP: Council of Managers for National Antarctic Programmes, www.comnap.aq, last access: January 2010.

Curran, M. A. and Jones, G. B.: Dimethyl sulfide in the Southern Ocean: seasonality and flux, J. Geophys. Res., 105, 2045120459, 2000.

Eisele, F., Davis, D. D., Helmig, C. D., Oltmans, S. J., Neff, W., Huey, G., Tanner, D., Chen, G., Crawford, J., Arimoto, R., Buhr, M., Mauldin, L., Hutterli, M., Dibb, J., Blake, D., Brooks, S. B., Johnson, B., Roberts, J. M., Wang, Y., Tan, D., and Flocke, F.: Antarctic tropospheric chemistry investigation (ANTCI) 2003 overview, Atmos. Environ. 42, 2749-2761, 2008.

Giggenbach, W. F., Kyle, P. R., and Lyon, G. L.: Present volcanic activity on Mount Erebus, Ross Island, Antarctica, Geology, 1, 135-136, 1973.

Hansen, J. and Nazarenko, L.: Soot climate forcing via snow and ice albedos, P. Natl. Acad. Sci., 101, 423-428, doi:10.1073/pnas.2237157100, 2004.

IAATO: International Association of Antarctic Tour Operators, www.iaato.org, last access: January 2010.

Langmann, B.: Numerical modelling of regional scale transport and photochemistry directly together with meteorological processes, Atmos. Environ., 34, 3585-3589, 2000.

Lugar, R. M.: Results of $\mathrm{PM}_{10}$ and TSP monitoring at McMurdo station, Antarctica, US Department of Energy, May 1993.

Mazzera, D. M., Lowenthal, D. H., Chow, J. C., Watson, J. G., and Grubisíc, V.: PM $_{10}$ measurements at McMurdo Station, Antarctica, Atmos. Environ., 35, 1891-1902, 2001.

Minikin, A., Legrand, M., Hall, J., Wagenbach, D., Kleefeld, C., Wolff, E., Pasteur, E.-C., and Ducroz, F.: Sulphur containing species (sulphate and methanesulfonate) in coastal Antarctic aerosol, J. Geophys. Res., 103(D9), 10975-10990, 1998.

Oppenheimer, C., Kyle, P. R., Tsanev, V. I., McGonigle, A. J. S., Mather, T. A., and Sweeney, D.: Mt. Erebus, the largest point source of $\mathrm{NO}_{2}$ in the Antarctic atmosphere, Atmos. Environ., 39, 6000-6006, 2005.

Oppenheimer, C., Kyle, P., Eisele, F., Crawford, J., Huey, G., Tanner, D., Kim, S., Mauldin, L., Blake, D., Beyersdorf, A., Buhr, M., and Davis, D.: Atmospheric chemistry of an Antarctic volcanic plume, J. Geophys. Res., in press, doi:10.1029/2009JD011910, 2010.

Shirsat, S. V. and Graf, H. F.: An emission inventory of sulfur from anthropogenic sources in Antarctica, Atmos. Chem. Phys., 9, 3397-3408, 2009, http://www.atmos-chem-phys.net/9/3397/2009/.

Skov, H., Wahlin, P., Christensen, J., Heidam, N. Z., and Petersen, D.: Measurements of elements, sulphate and $\mathrm{SO}_{2}$ in Nuuk Greenland, Atmos. Environ., 40, 4775-4781, 2006.

Stockwell, W. R., Middleton, P., Chang, J. S., and Tang, X.: The second generation regional acid deposition model: Chemical mechanism for regional air quality modelling, J. Geophys. Res., 95, 16343-16367, 1990.

Stohl, A. and Sodemann H.: Characteristics of atmospheric transport into the Antarctic troposphere, J. Geophys. Res., 115, DO2305, doi:10.1029/2009JD012536, 2010.

Sweeney, D., Kyle, P. R., and Oppenheimer, C.: Sulfur dioxide emissions and degassing behavior of Erebus volcano, Antarctica, 
J. Volcanol. Geoth. Res., 177, 725-733, 2008.

Tin, T., Fleming, Z. L., Hughes, K. A., et al.: Impacts of local human activities on the Antarctic environment, Antarct. Sci., 21(1), 3-33, 2009.

Uppala, S. M., Kallberg, P. W., Simmons, A. J., et al.: The ERA-40 re-analysis, Q. J. Roy. Meteorol. Soc., 131, 2961-3012, 2005.

Wang, Y., Choi, Y., Zng, T., Davis, D., Buhr, M., Huey, L. G., and Neff, W.: Assessing the photochemical impact of snow NOx emissions over Antarctica during ANTCI 2003, Atmos. Environ., 42(12), 2849-2863, 2008.
Walcek, C. J. and Taylor, G. R.: A theoretical method for computing vertical distributions of acidity and sulfate production within cumulus clouds, J. Atmos. Sci., 43, 339-355, 1986.

Wesley, M. L.: Parameterization of surface resistances to gaseous dry deposition in regionalscale numerical models, Atmos. Environ., 23, 1293-1304, 1989.

Wolff, E. W. and Cachier, H.: Concentrations and seasonal cycle of Black Carbon aerosol in a coastal Antarctic station, J. Geophys. Res., 103(D9), 11033-11041, 1998. 